\title{
Expression of the polycomb group gene Bmi1 does not affect the prognosis of pediatric acute lymphoblastic leukemia
}

\author{
Teruyuki Kajiume*, Nobutsune Ishikawa, Norioki Ohno, Yasuhiko Sera, Syuhei Karakawa, \\ Masao Kobayashi
}

Department of Pediatrics, Graduate School of Biomedical Sciences, Hiroshima University, Hiroshima, Japan;

*Corresponding Author: kajiume@hiroshima-u.ac.jp

Received 23 December 2011; revised 20 January 2012; accepted 29 February 2012

\begin{abstract}
The Polycomb group protein Bmi1 is a constituent of the Polycomb repressive complex 1 , and it is an important molecule for the regulation of the self-renewal of hematopoietic stem cells. In the field of clinical hematology, there are reports that the level of Bmi1 expression in blast cells is related to the prognosis of acute myeloid leukemia, chronic myeloid leukemia, and myelodysplastic syndrome. We investigated whether the level of Bmi1 expression in leukemic cells is related to the prognosis and the characteristics of childhood acute lymphoblastic leukemia. In all the leukemic blast cells, Bmi1 gene expression was lower value than that in normal $B$ cells. There were no correlations between the level of Bmi1 gene expression in leukemic blast cells and other parameters, including prognosis. Here, we report that the level of Bmil expression in blast cells is not related to the prognosis of pediatric acute lymphoblastic leukemia.
\end{abstract}

Keywords: Acute Lymphoblastic Leukemia; Leukemic Stem Cell; Bmi1; Polycomb

\section{INTRODUCTION}

Mammalian Polycomb group (PcG) protein complexes can be classified into 2 distinct types, Polycomb represssive complex 1 (PRC1) and PRC2. The PcG protein Bmil is a constituent of PRC1 [1-5]. Bmil is an important molecule for the self-renewal of hematopoietic stem cells (HSCs). The expression of Bmil is generally high in HSCs but decreases after these cells differentiate $[6,7]$. Some reports in the field of clinical hematology have shown that the expression level of Bmil in blast cells of acute myeloid leukemia (AML), chronic myeloid leukemia (CML), and myelodysplastic syndrome (MDS) can be related to the prognosis of the disease [8-10]. According to these reports, leukemia cells that have a high Bmil expression are correlated with poor prognosis. Cancer stem cells in AML were identified for the first time in 1997. In that study, CD38-/CD34+ cells together with leukemic cells were injected into non-obese diabetic mice with severe combined immunodeficiency disease, and the injected mice developed AML [11]. Subsequently, stem cells of breast cancer, brain tumor, prostate cancer, colon cancer, and pancreatic cancer were successively reported [12-16]. Although there are reports on the stem cells of acute lymphoblastic leukemia, these are fewer than those on other cancers $[17,18]$. A high expression of Bmil, which has been reported for many cancer stem cells, might be the reason for some cancers becoming chemoresistant $[19,20]$. We investigated whether Bmi1 expression is related to the prognosis and cell properties of pediatric acute lymphoblastic leukemia.

\section{MATERIALS AND METHODS}

\subsection{Patients}

Because childhood leukemia is usually precursor B leukemia, we limited our investigation to pediatric precursor B acute lymphoblastic leukemia. According to the Declaration of Helsinki, informed consent and permission were obtained from all patients. Leukemic blast cells were collected from patients who had been diagnosed with pediatric precursor B acute lymphoblastic leukemia at Hiroshima university hospital from January 2002 to September 2006. These leukemic blast cells were used for real-time polymerase chain reaction (RT-PCR). Cells were obtained from only those patients in whom the percentage of leukemic cells was higher than $90 \%$, and only CD19+ cells were chosen.

\subsection{Flow Cytometric Cell Sorting}

The bone marrow-derived cells were labeled with dif- 
ferent antibodies to sort each hematopoietic lineage. CD34+/CD38-, CD34+/CD38-/CD10-, CD34+/CD38+/ $\mathrm{CD} 10+, \mathrm{CD} 3+$, and $\mathrm{CD} 19+$ cells were treated as HSCs, common myeloid progenitors, common lymphoid progenitors, T cells, and B cells, respectively. Dead cells that positively stained with propidium iodide were excluded. The cells were sorted using a FACS Aria system (BD Biosciences, Bedford, MA). Sorted cells with a purity of at least $95 \%$ were used for further experimentation.

\subsection{Real Time RT-PCR}

The TaqMan RT-PCR was used for quantitative gene analysis (TaqMan PCR; Applied Biosystems, Foster City, $\mathrm{CA}$ ). The sequences of the specific primers were as follows: Bmi1, sense primer: 5'-AAA TGC ATC GAA CAA CGA GAA TC-3' and antisense primer: 5'-AAT GAA GTA CCC TCC ACA AAG CA-3'; GAPDH, sense primer: 5'-GAA GGT GAA GGT CGG AGT-3' and antisense primer: 5'-CTT TAG GGT AGT GGT AGA AG-3'. The sequences of the 5'-FAM3'-TAMRA labeled probes were as follows: Bmi1, 5'-CAG GTG GGG ATT TAG CTC AG-3' and GAPDH, 5'-CCG ACT CTT GCC CTT CGA AC-3'. The relative quantification ( $\triangle \Delta C T$ method) was used for quantitative analysis.

\subsection{Statistical Analysis}

The correlation coefficient was analyzed with Pearson product-moment correlation coefficient. Welch's t test was used for analyzed between 2 groups.

\section{RESULTS}

Firstly, we purified the cell populations of each differentiation stage, including the HSCs from the bone marrow of healthy volunteers and analyzed the expression of the Bmil gene. The expression of the Bmil gene is high in HSCs, and decreases when the cells enter the differentiation stage, as shown Figure 1(a). This result is in agreement with a previous report [21]. The inhibition of T-cell differentiation has been reported in Bmil-deficient mice [22]. Therefore, it is thought that Bmil is essential for T-cell maturation. The expression of the Bmil gene was high in $\mathrm{T}$ cells in moderation. The expression of the Bmil gene did not increase when B cells underwent differentiation. These results are summarized in the schema (Figure 1(b)). The expression of Bmil in HSCs is 1.0. The expression of the Bmil gene was lower than HSCs at all hematopoietic stages. In other words, the expression of the Bmil gene decreased during the differentiation of the hematopoietic cells. In addition, it seems that undifferentiated cells have a high level of Bmil expression.

Table 1 summarizes the basic data of all participants such as the peripheral blood white blood cell count, cell properties, and age. Unfortunately, 4 patients (Nos. 12 - 14)

Table 1. Summary of the patients' profiles, cell profiles, and the level of Bmil expression.

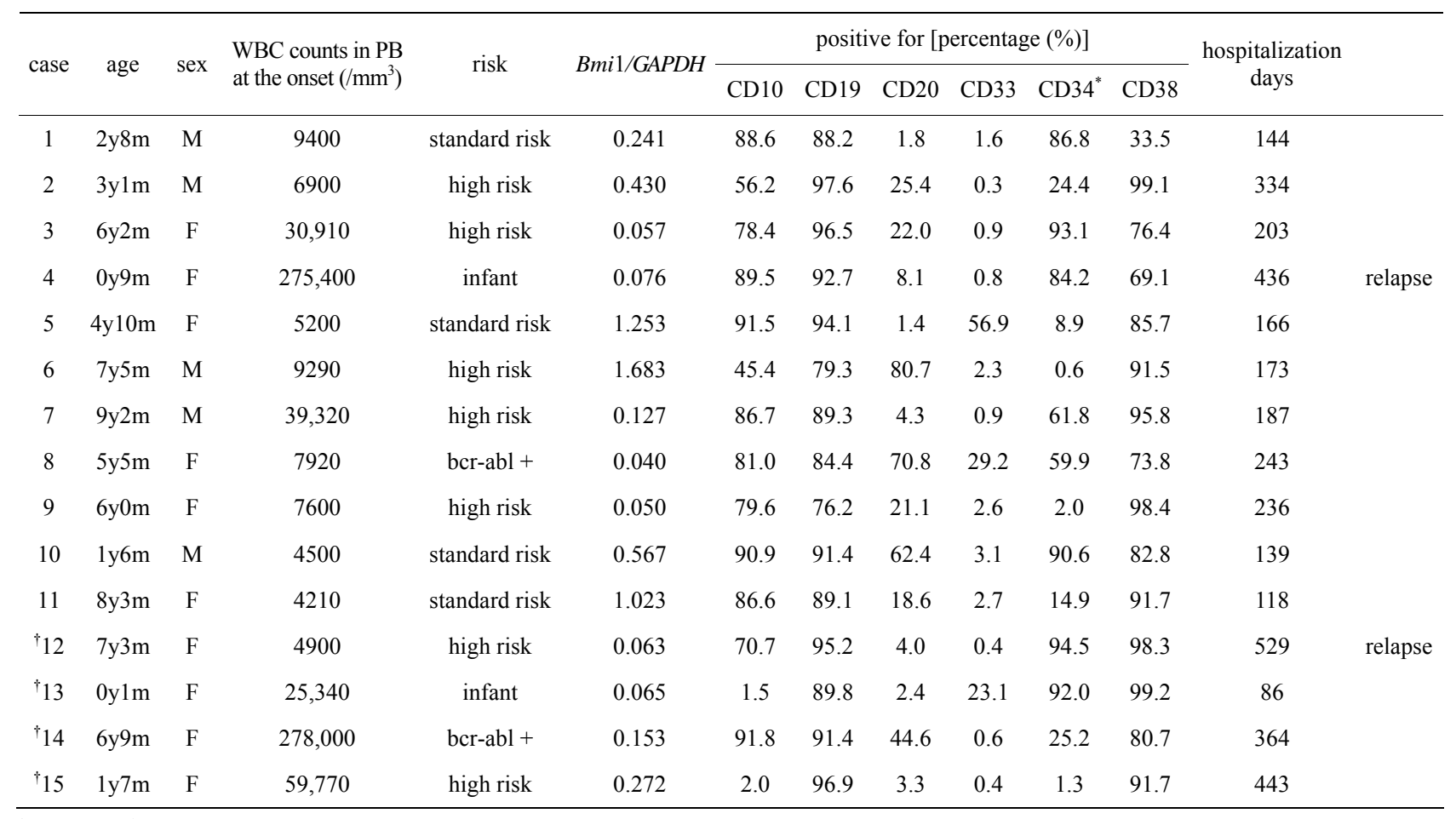

'death case; ${ }^{*} \mathrm{p}<0.05$. 

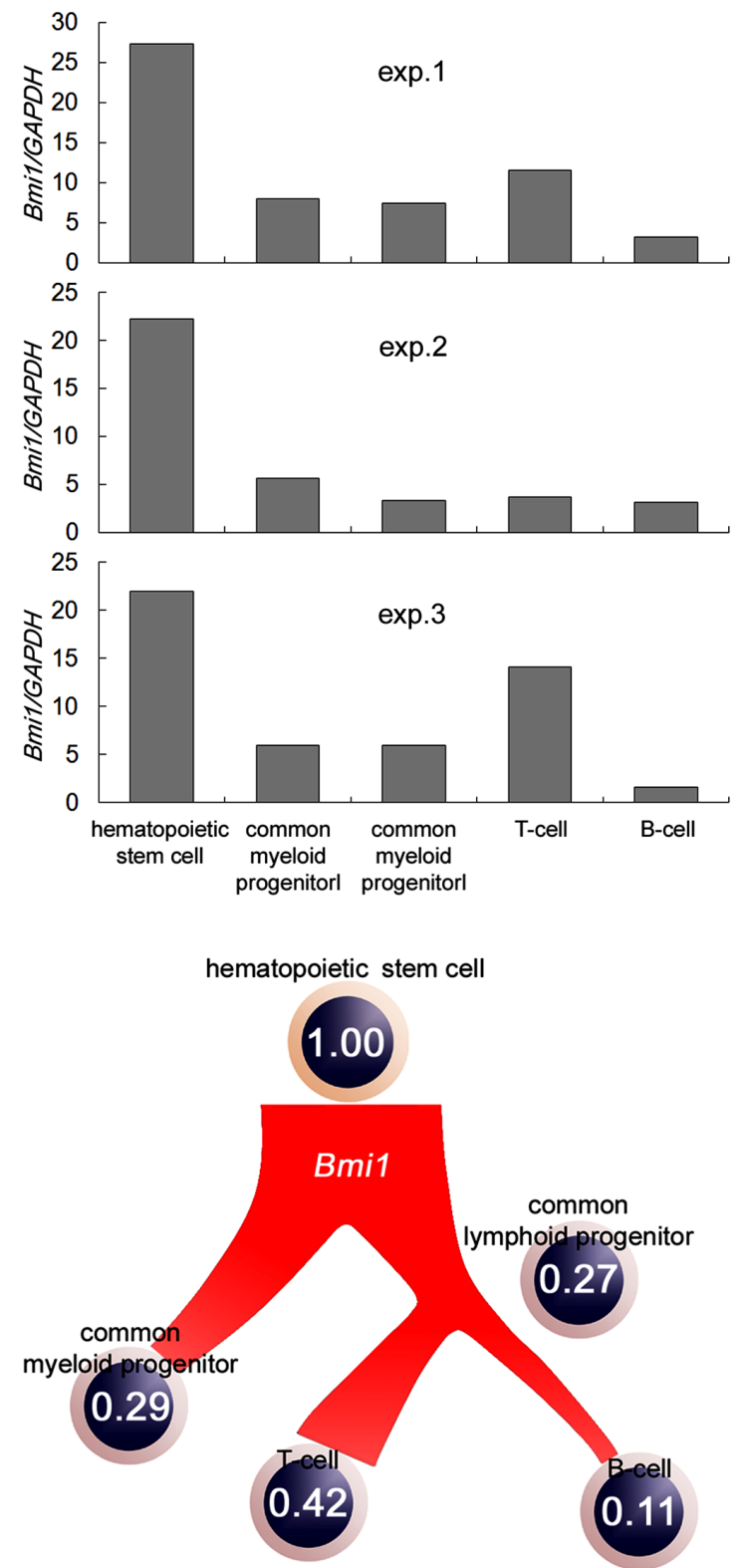

Figure 1. Quantitative analysis of Bmil gene expression of each hematopoietic cell type. (a) CD34+/CD38-, CD34+/ CD38+/CD10-, CD34+/CD38+/CD10 +, CD3+, and CD19+ cells were treated as HSCs, common myeloid progenitors, common lymphoid progenitors, T cells, and $\mathrm{B}$ cells, respectively. The expression of Bmil increased in immature cells; (b) Bmil gene expression in each lineage are shown in the schema. The expression of the Bmil gene decreased during the differentiation of hematopoietic cells.

died in spite of treatment. Figure 2(a) compares Bmil gene expression in the blast cells and B cells (CD19+ cells) from the bone marrow of healthy donors. Bmi1 gene expression in all blast cells was low compared to normal B cells. There was no correlation between the prognosis of the patients and the level of Bmil gene ex-

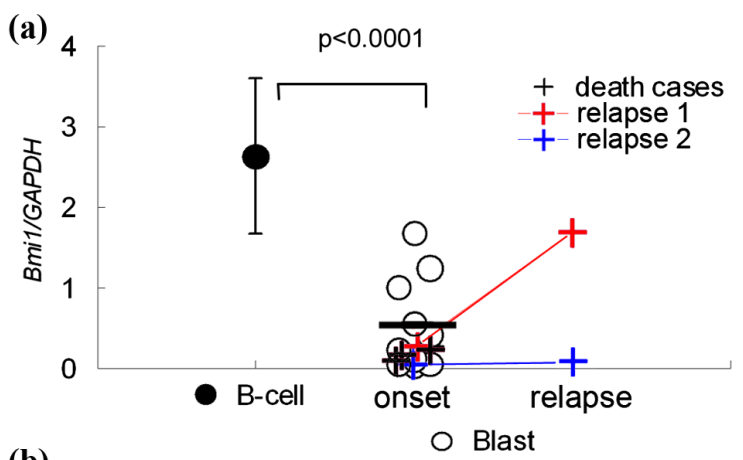

(b)
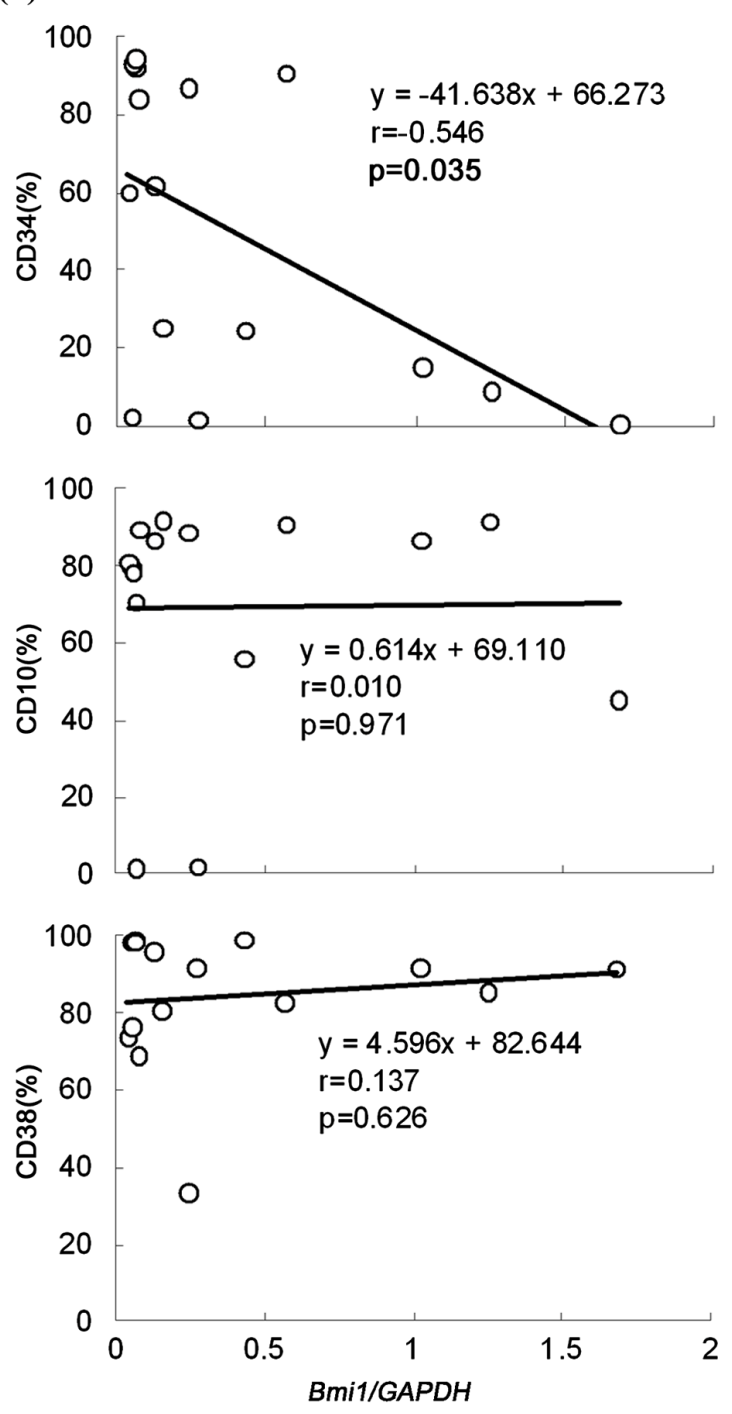

Figure 2. Comparison of the level of Bmil expression in normal B cells and precursor B cells of acute lymphoblastic leukemia. (a) The level of Bmil expression is significantly decreased in all leukemic cells as compared to normal B cells. The level of Bmil expression was not significantly different between recurrent cases and death cases. Error bars indicate standard deviation; (b) There was a correlation between Bmil gene expression and the cell surface marker CD34. There was no significant difference between other surface markers. 
pression. The expression of the Bmil gene was analyzed using cells from the bone marrow at the time of recurrence in 2 cases (of 4 relapse cases). In one of these 2 cases, Bmil expression in the blast cells increased from the first onset but did not change in the second case. However, both patients had low expression levels compared to normal B cells. There was a negative correlation between $B m i 1$ gene expression and the cell surface marker CD34 (Figure 2(b)). It is known that human HSCs harbor the CD34 antigen. Therefore, we expected that CD34+ cells are undifferentiated cells and express Bmil. However, this result was contrary to our expectation.

\section{DISCUSSION}

We investigated whether the level of Bmil gene expression in pediatric precursor $B$ leukemic cells is related to the clinical course, cell profile, and prognosis. There are reports on a relationship between the prognosis of hematopoietic malignancies and $B m i 1$ gene expression. Especially in AML, CML, and MDS, when the expression of the Bmil gene increased in leukemic blasts, the prognosis was bad [8-10]. Yet, the reason for this is not known. However, the Bmil protein regulates the p16INK4a protein, which is one of the CDK (cylcin-dependent kinase) inhibitors [23]. In addition, the proliferation of leukemic cells may increase due to Bmil expression. Bmil is an essential molecule for the selfrenewal of HSCs. It has been reported that the selfrenewal of HSCs reduces remarkably in Bmil-deficient mice [7]. Immature cells such as HSCs have a high expression of Bmil, and Bmil expression decreases in developed cells during differentiation $[21,24]$. It has been reported that the expression of the Bmil gene is high in side population cells such as cancer stem cells in heaptocellular carcinoma [25]. It can be expected that the expression of the Bmil gene increases in cancer stem cells according to these previous studies. Usually, cancer stem cells are chemoresistant. In addition, it was shown that cancer stem cells are involved in cancer recurrence [26-28]. A high expression of Bmi1, which has been reported for many cancer stem cells, might be the reason for some cancers becoming chemoresistant $[19,20]$. Therefore, there is the possibility that the cancer cells are not exterminated, and the prognosis of the patient worsens. In acute lymphoblastic leukemia, it was reported that CD90+/CD110+ cells in acute lymphoblastic T-cell leukemia, and CD9-overexpressing cells in acute lymphoblastic B-cell leukemia, are cancer stem cells $[17,18]$. Although these data were collected from in vitro experiments, the existence of cancer stem cells in primary precursor B acute lymphoblastic leukemia cells and pediatric acute lymphoblastic leukemia cells is not clarified yet. In our data, there was the significance of the negative correlation between CD34 and Bmil expression of blast cells. Generally, it is known that human CD34 positive cells are immature cells. When there are many immature cells, poor prognosis was expected. There were a few reports that $\mathrm{CD} 34$ is a prognostic factor in adults with acute myelocytic leukemia $[29,30]$. However, there were no reports showing the relation between $\mathrm{CD} 34$ and prognosis of acute lymphoblastic leukemia. Both CD34 and the expression of Bmil were not correlated with prognosis in our data. Bmil expression in pediatric acute lymphoblastic leukemia cells is lower than that in normal B cells. We do not know why the Bmil expression in pediatric acute lymphoblastic leukemia cells is lower than Bmil expression in B-cells. Although it is our speculation, pediatric acute lymphoblastic leukemia cells are no longer in immature. Moreover, cancer stem cells in pediatric acute acute lymphoblastic leukemia may be nonexistent.

\section{CONCLUSION}

We investigated whether the level of Bmil expression in leukemic cells is related to the prognosis and the characteristics of childhood acute lymphoblastic leukemia. From this result, it will be a very small number even if immature cells like cancer stem cells exist. In addition, there is no correlation between Bmil expression and the prognosis of pediatric acute lymphoblastic leukemia. Cancer stem cells may not exist in pediatric acute lymphoblastic leukemia. However, the number of people participating in the experiment is not enough in this study. We consider the samples from more patients with leukemia will be necessary to lead certain conclusion.

\section{ACKNOWLEDGEMENTS}

We are indebted to the pediatric hematologists (Drs. Takashi Sato, M.D., Shinichiro Nishimura, M.D., Hiroshi Kawaguchi, M.D., Kazuhiro Nakamura, M.D., and Mizuka Miki, M.D.) and nurses for providing excellent patient care.

We thank the Analysis Center of Life Science, Hiroshima University, for allowing us to use their facilities.

\section{REFERENCES}

[1] Alkema, M.J., Bronk, M., Verhoeven, E., Otte, A., van’t Veer, L.J., Berns. A. and van Lohuizen. M. (1997) Identification of Bmil-interacting proteins as constituents of a multimeric mammalian polycomb complex. Genes \& Development, 11, 226-240. doi:10.1101/gad.11.2.226

[2] Gunster, M.J., Satijn, D.P., Hamer, K.M., den Blaauwen, J.L., de Bruijn, D., Alkema, M.J., van Lohuizen, M., van Driel, R. and Otte, A.P. (1997) Identification and characterization of interactions between the vertebrate polycombgroup protein Bmil and human homologs of polyhomeotic. Molecular and Cellular Biology, 17, 2326-2335. 
[3] Hashimoto, N., Brock, H.W., Nomura, M., Kyba, M., Hodgson, J., Fujita, Y., Takihara, Y., Shimada, K. and Higashinakagawa, T. (1998) RAE28, Bmi1, and M33 are members of heterogeneous multimeric mammalian polycomb group complexes. Biochemical and Biophysical Research Communications, 245, 356-365. doi:10.1006/bbrc.1998.8438

[4] Shao, Z., Raible, F., Mollaaghababa, R., Guyon, J.R., Wu, C.T., Bender, W. and Kingston, R.E. (1999) Stabilization of chromatin structure by PRC1, a polycomb complex. Cell, 98, 37-46. doi:10.1016/S0092-8674(00)80604-2

[5] Francis, N.J., Saurin, A.J., Shao, Z. and Kingston, R.E. (2001) Reconstitution of a functional core polycomb repressive complex. Molecular Cell, 8, 545-556. doi:10.1016/S1097-2765(01)00316-1

[6] Park, I.K., Qian, D., Kiel, M., Becker, M.W., Pihalja, M., Weissman, I.L., Morrison, S.J. and Clarke, M.F. (2003) $\mathrm{Bmi}-1$ is required for maintenance of adult self-renewing haematopoietic stem cells. Nature, 423, 302-305.

[7] Lessard, J. and Sauvageau, G. (2003) Bmi-1 determines the proliferative capacity of normal and leukaemic stem cells. Nature, 423, 255-260.

[8] Chowdhury, M., Mihara, K., Yasunaga, S., Ohtaki, M., Takihara, Y. and Kimura, A. (2007) Expression of polycomb-group (PcG) protein Bmi-1 predicts prognosis in patients with acute myeloid leukemia. Leukemia, 21, 11161122. doi:10.1038/sj.leu.2404623

[9] Mohty, M., Yong, A.S., Szydlo, R.M., Apperley, J.F. and Melo, J.V. (2007) The polycomb group Bmil gene is a molecular marker for predicting prognosis of chronic myeloid leukemia. Blood, 110, 380-383. doi:10.1182/blood-2006-12-065599

[10] Mihara, K., Chowdhury, M., Nakaju, N., Hidani, S., Ihara, A., Hyodo, H., Yasunaga, S., Takihara, Y. and Kimura, A. (2006) Bmi-1 is useful as a novel molecular marker for predicting progression of myelodysplastic syndrome and patient prognosis. Blood, 107, 305-308. doi:10.1182/blood-2005-06-2393

[11] Bonnet, D. and Dick, J.E. (1997) Human acute myeloid leukemia is organized as a hierarchy that originates from a primitive hematopoietic cell. Nature Medicine, 3, 730737. doi:10.1038/nm0797-730

[12] Al-Hajj, M., Wicha, M.S., Benito-Hernandez, A., Morrison, S.J. and Clarke, M.F. (2003) Prospective identification of tumorigenic breast cancer cells. Proceedings of the National Academy of Sciences of the United States of America, 100, 3983-3988. doi: 10.1073/pnas.0530291100

[13] Singh, S.K., Clarke, I.D., Terasaki, M., Bonn, V.E., Hawkins, C., Squire, J. and Dirks, P.B. (2003) Identification of a cancer stem cell in human brain tumors. Cancer Research, 63, 5821-5828.

[14] Xin, L., Lawson, D.A. and Witte, O.N. (2005) The Sca-1 cell surface marker enriches for a prostate-regenerating cell subpopulation that can initiate prostate tumorigenesis. Proceedings of the National Academy of Sciences of the United States of America, 102, 6942-6947. doi:10.1073/pnas.0502320102

[15] Ricci-Vitiani, L., Lombardi, D.G., Pilozzi, E., Biffoni, M., Todaro, M., Peschle, C. and De Maria, R. (2007) Identi- fication and expansion of human colon-cancer-initiating cells. Nature, 445, 111-115.

[16] Li, C., Heidt, D.G., Dalerba, P., Burant, C.F., Zhang, L., Adsay, V., Wicha, M., Clarke, M.F. and Simeone, D.M. (2007) Identification of pancreatic cancer stem cells. Cancer Research, 67, 1030-1037. doi: 10.1158/0008-5472.CAN-06-2030

[17] Yamazaki, H., Nishida, H., Iwata, S., Dang, N.H. and Morimoto, C. (2009) CD90 and CD110 correlate with cancer stem cell potentials in human T-acute lymphoblastic leukemia cells. Biochemical and Biophysical Research Communications, 383, 172-177. doi:10.1016/j.bbrc.2009.03.127

[18] Nishida, H., Yamazaki, H., Yamada, T., Iwata, S., Dang, N.H., Inukai, T., Sugita, K., Ikeda, Y. and Morimoto, C. (2009) CD9 correlates with cancer stem cell potentials in human B-acute lymphoblastic leukemia cells. Biochemical and Biophysical Research Communications, 382, 5762. doi:10.1016/j.bbrc.2009.02.123

[19] Zhang, S., Balch, C., Chan, M.W., Lai, H.C., Matei, D., Schilder, J.M., Yan, P.S., Huang, T.H. and Nephew, K.P. (2008) Identification and characterization of ovarian cancer-initiating cells from primary human tumors. Cancer Research, 68, 4311-4320. doi:10.1158/0008-5472.CAN-08-0364

[20] Wang, E., Bhattacharyya, S., Szabolcs, A., RodriguezAguayo, C., Jennings, N.B., Lopez-Berestein, G., Mukherjee, P., Sood, A.K. and Bhattacharya, R. (2011) Enhancing chemotherapy response with $\mathrm{Bmi}-1$ silencing in ovarian cancer. PLoS One, 6, p. e17918. doi:10.1371/journal.pone.0017918

[21] Lessard, J., Baban, S. and Sauvageau, G. (1998) Stagespecific expression of polycomb group genes in human bone marrow cells. Blood, 91, 1216-1224.

[22] Miyazaki, M., Miyazaki, K., Itoi, M., Katoh, Y., Guo, Y., Kanno, R., Katoh-Fukui, Y., Honda, H., Amagai, T., van Lohuizen, M., Kawamoto, H. and Kanno, M. (2008) Thymocyte proliferation induced by pre-T cell receptor signaling is maintained through polycomb gene product Bmi1-mediated Cdkn2a repression. Immunity, 28, 231-245. doi:10.1016/j.immuni.2007.12.013

[23] Jacobs, J.J., Kieboom, K., Marino, S., DePinho, R.A. and van Lohuizen, M. (1999) The oncogene and polycombgroup gene bmi-1 regulates cell proliferation and sensecence through the ink4a locus. Nature, 397, 164-168.

[24] Hosen, N., Yamane, T., Muijtjens, M., Pham, K., Clarke, M.F. and Weissman, I.L. (2007) Bmi-1-green fluorescent protein-knock-in mice reveal the dynamic regulation of bmi-1 expression in normal and leukemic hematopoietic cells. Stem Cells, 25, 1635-1644. doi:10.1634/stemcells.2006-0229

[25] Chiba, T., Miyagi, S., Saraya, A., Aoki, R., Seki, A., Morita, Y., Yonemitsu, Y., Yokosuka, O., Taniguchi, H., Nakauchi, H. and Iwama, A. (2008) The polycomb gene product Bmil contributes to the maintenance of tumorinitiating side population cells in hepatocellular carcinoma. Cancer Research, 68, 7742-7749. doi:10.1158/0008-5472.CAN-07-5882

[26] Liu, G., Yuan, X., Zeng, Z., Tunici, P., Ng, H., Abdulkadir, 
I.R., Lu, L., Irvin, D., Black, K.L. and Yu, J.S. (2006) Analysis of gene expression and chemoresistance of CD133+ cancer stem cells in glioblastoma. Molecular Cancer, 5, 67-78. doi:10.1186/1476-4598-5-67

[27] Gutova, M., Najbauer, J., Gevorgyan, A., Metz, M.Z., Weng, Y., Shih, C.C. and Aboody, K.S. (2007) Identification of uPAR-positive chemoresistant cells in small cell lung cancer. PLOS ONE, 2, e243. doi:10.1371/journal.pone. 0000243

[28] Shafee, N., Smith, C.R., Wei, S., Kim, Y., Mills, G.B., Hortobagyi, G.N., Stanbridge, E.J. and Lee, E.Y. (2008) Cancer stem cells contribute to cisplatin resistance in Brca1/p53-mediated mouse mammary tumors. Cancer
Research, 68, 3243-3250. doi:10.1158/0008-5472.CAN-07-5480

[29] Geller, R.B., Zahurak, M., Hurwitz, C.A., Burke, P.J., Karp, J.E., Piantadosi, S. and Civin, C.I. (1990) Prognostic importance of immunophenotyping in adults with acute myelocytic leukaemia: The significance of the stemcell glycoprotein CD34 (My10). British Journal of Haematology, 76, 340-347. doi:10.1111/j.1365-2141.1990.tb06365.x

[30] Myint, H. and Lucie, N.P. (1992) The prognostic significance of the CD34 antigen in acute myeloid leukaemia. Leukemia \& Lymphoma, 7, 425-429. 